\title{
Proceeding
}

Supplementary Issue: Rio 2016 Olympic Games Second Anniversary Special Edition. Olympic Studies Forum, 2-3 October 2018.

Federal University of Espirito Santo, (Vitória - Espirito Santo), Brazil

\section{Possibilities of Olympic Legacy Rio 2016: A systematic review}

\author{
LEONARDO PEROVANO CAMARGO , OTÁVIO GUIMARÃES TAVARES DA SILVA
}

Federal University of Espírito Santo (UFES), Brazil

\begin{abstract}
In the last two decades Brazil has been the scene of several mega-sports events, putting it in evidence in the international scenario and culminating with the Rio 2016 Olympics. The methodology of this article is designed in the form of a systematic review. Thus, the question that guided this systematic review refers to the identification of central themes that guided the academic debate on legacies of sports mega-events, and the possibility to observe the variables. Through the systematic review technique, it was concluded, after reading and analyzing the selected articles, that these are the possibilities and dominant themes in the debate on legacies: multidisciplinarity, education, public health, inclusion, politics, social conflicts and environmental rights. Keywords: Politics; Sports; Education; Social conflicts.
\end{abstract}

\section{Cite this article as:}

Camargo, L.P., \& Tavares, O.G. (2019). Possibilities of Olympic Legacy Rio 2016: A systematic review. Journal of Human Sport and Exercise, 14(3proc), S321-S327.

doi:https://doi.org/10.14198/jhse.2019.14.Proc3.05

Corresponding author. Rua Santa Catarina, 223, Carapina, Serra-ES, Brazil.

E-mail: leonardoperovano@gmail.com

Supplementary Issue: Rio 2016 Olympic Games Second Anniversary Special Edition. Olympic Studies Forum, 2-3 October 2018. Federal University of Espírito Santo, (Vitória - Espírito Santo), Brazil.

JOURNAL OF HUMAN SPORT \& EXERCISE ISSN 1988-5202

(c) Faculty of Education. University of Alicante

doi:10.14198/jhse.2019.14.Proc3.05 


\section{INTRODUCTION}

In the last two decades Brazil has been the scene of several mega-sport events, putting it in evidence in the international scenario. From the 2007 Pan American Games to the 2016 Olympics, these mega events shaped public opinion and raised debates about transformations in culture and structural changes in urban equipment.

The Olympic Games are the biggest sporting and cultural event in the world and in the Rio 2016 edition they brought glances, at first with great distrust, to a South American country for the first time in history. Despite the success of the event itself, the series of demands on structural investments raises the question of whether the Olympics were a good deal for the country as a whole.

Brazil hosted the Olympic Games two years ago, so this theme should be in evidence. But it is clear that the discussion about legacy was intense before the Games and had a great decline afterwards. There was an anticipated mood of absolute pessimism, replaced by euphoria during competitions and an uncomfortable silence afterwards.

It seems possible to state that there was a social belief that mega-events could solve social, sporting, financial, political, cultural problems, among others, as if in a magical way, although "they cannot be seen as a panacea for economic and social problems"(Tavares, 2011, p. 30).

According to Villano et al (2008), "sports mega-events have their high investments justified by their capacity to function as a catalyst for a number of necessary changes".

To achieve and equation the investment account in mega-events versus returns and legacies is not easy. So this kind of analysis has been turning into a large and complex multidisciplinary web. When we think in legacy, according to Villano et al. (2008) we need to focus on five main points: Legacies of the event itself, legacies of the application process, legacies to the international image of the host country, legacies of governance and the legacies of acquired knowledge. In other words, there is a multidimensional sense of legacy (Mazo; Rolim; DaCosta, 2008) in which tangible legacies (quantitative analysis) and intangible (cultural impact) on the dimensions of time (before, during and after the Games) and spaces (from the host city to other units of the federation).

However, the need to better define legacies and thus the cost-effectiveness of a mega-sport event has led the International Olympic Committee (IOC) to place 'monitoring of post-Games legacies' as a central point on the contemporary Olympic agenda. In this context, in its fourth recommendation, the 2020 Olympic Agenda, states that post-Olympic monitoring of the Olympic Legacy must be guaranteed (IOC, 2014, p.7).

\section{MATERIAL AND METHODS}

The methodology of this article is designed in the form of a systematic review. Because of this methodological choice, this section seeks to gather, critically evaluate and synthesize results from several primary studies with the intention of answering the question (problem) of the research. The systematic review is classified, like any review, as retrospective observational studies (Cordeiro et al., 2007). 
Studies using the observational method are the most frequent in the social sciences because any research of this nature needs to observe some fact that happens or happened, without necessarily interfering or concluding causal relations in the observed facts (Gil, 2008).

The fact we are observing in this review is the Olympic Games that occurred in Rio in 2016, and one point that was well discussed socially from this Mega-event was the Olympic Legacy. In the analysis of the Legacy benchmarking of other countries, we can see a temporal period in which there was an adaptation of the plans and the actual construction of the Legacy, in order to define a more assertive assessment of the limits and possibilities of these Mega-events.

Thus, the question that guided this systematic review refers to the identification of central themes that guided the academic debate on legacies of sports mega-events, and it is possible to observe the variables.

The delimited time frame was the period from 2013 to 2017, that is, one year after the London 2012 Games and up to one year after the Rio 2016 Games. This allows the possibility of observing the evidences of legacy before 2016 and after the event of the Games.

As descriptors (keywords) in Portuguese language, it was decided to use the terms 'Legado Olímpico' in several search bases and to conduct two initial rounds of analysis, one by title and another by the abstract, both to analyse the possibility of inclusion. In the search base where the English language is the standard, the descriptors used were: 'Olympic Legacy'.

As exclusion criteria, articles that deal exclusively with events other than the Olympics or that deal exclusively with the Olympic legacy of other countries, excluding Brazil, were chosen. Thus, only articles dealing with the Olympic Legacy Rio 2016 were selected for further analysis.

The selected search bases were: the 'Portal de Periódicos da CAPES (Coordination of Improvement of Higher Level Personnel)' for the possibility of returning more results when performing the digital search using a station within the UFES (Federal University of Espirito Santo), there is the availability of more documents in research carried out inside the federal universities in Brazil (currently); the portal of 'Scielo' articles, for being a recognized portal of Brazilian scientific articles of open access; and the portal 'Sociological Abstracts' for being a recognized source of international scientific articles in Social Sciences.

\section{RESULTS}

The 'grey literature' (literature not controlled by scientific editors, such as government reports, thesis, dissertations, and abstracts) was discarded from the sample, opting only for peer-reviewed scientific articles. In the option of languages, we opted for the inclusion of articles in the Portuguese and English languages, due to their relevance in the research problem and the researcher's domain.

From these definitions, the practical part of the systematic review was carried out, within the aforementioned search mechanisms. Thus, the search on 11 of January of 2018 returned a total of 90 entries, 40 of CAPES, 5 of Scielo and 45 of the portal Sociological Abstracts. 


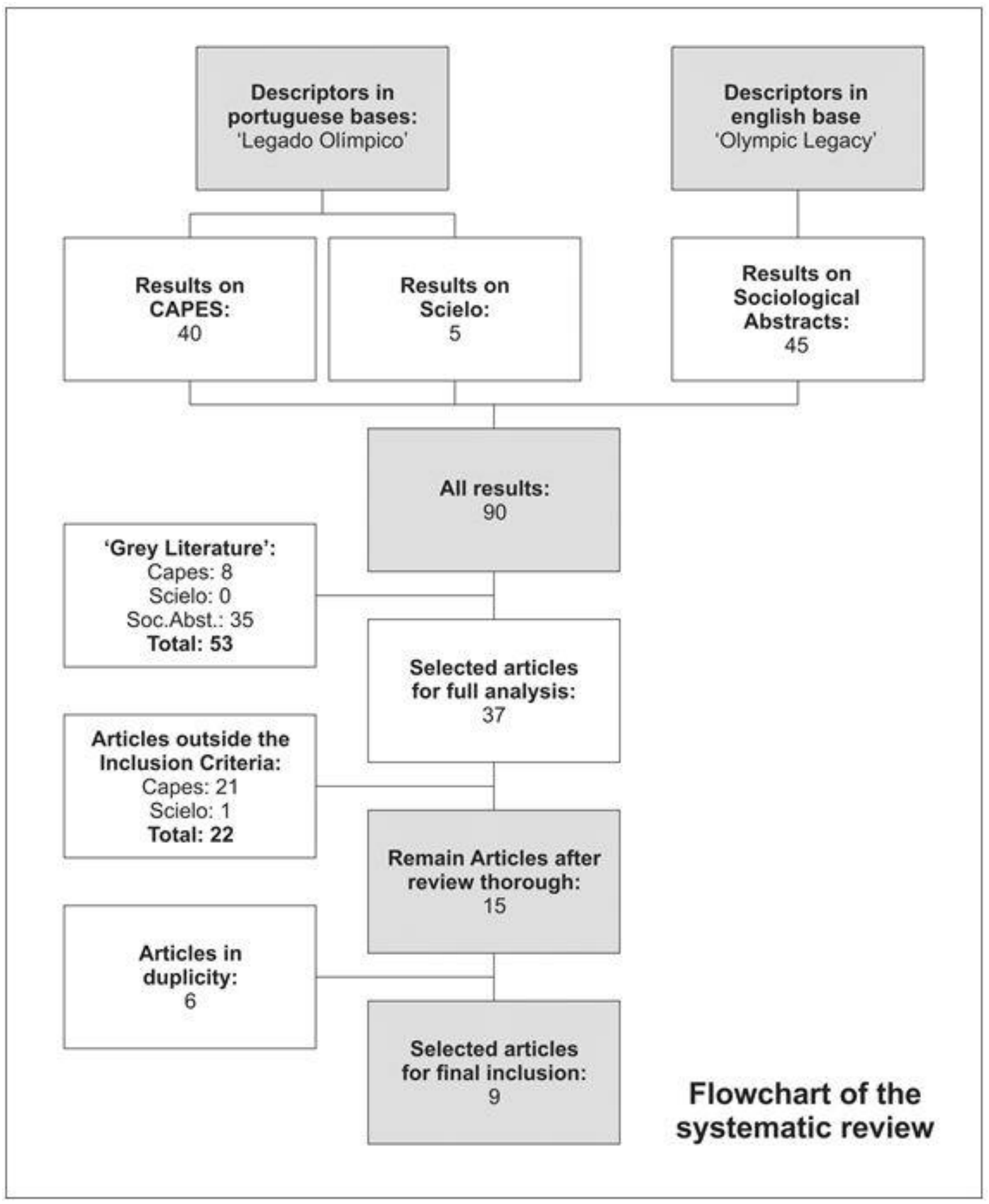

Figure 1. Flowchart of the systematic review of the research (Source: Researcher).

After the filtering process shown in Figure 1 we obtained the following search results: 
Table 1. Selected articles after analysis of systematic review (Source: Researcher)

\begin{tabular}{|c|c|c|}
\hline Title & $\begin{array}{l}\text { Author, Year and } \\
\text { Journal }\end{array}$ & Results \\
\hline Olympic legacy: a multidisciplinary heritage & $\begin{array}{l}\text { Pereira, } 2016 . \\
\text { Motricidade. }\end{array}$ & $\begin{array}{l}\text { Implement a National Sports } \\
\text { Policy. Regular, curricular and } \\
\text { pedagogical practice of Physical } \\
\text { Education. }\end{array}$ \\
\hline Olympic legacy for Brazil: public health issue? & $\begin{array}{l}\text { Demarzo et al, } 2014 . \\
\text { Cadernos de Saúde } \\
\text { Pública. }\end{array}$ & $\begin{array}{l}\text { It is necessary to evaluate the } \\
\text { impact of the Olympic Games on } \\
\text { the health of Brazilians. }\end{array}$ \\
\hline $\begin{array}{l}\text { Olympic education for what? Olympic } \\
\text { education for whom? Representations and } \\
\text { practices for critical pedagogy in special } \\
\text { topics of Olympism-the doping between } \\
\text { school }\end{array}$ & $\begin{array}{l}\text { Maturana, } 2014 . \\
\text { Podium. }\end{array}$ & $\begin{array}{l}\text { Increased investments in studies } \\
\text { and interventions that will discuss } \\
\text { the aspects of Olympism } \\
\text { Education more broadly. }\end{array}$ \\
\hline $\begin{array}{l}\text { Olympic and Paralympic games in Brazil: } \\
\text { learning from Barcelona and Sydney }\end{array}$ & $\begin{array}{l}\text { Vila et al, } 2014 . \\
\text { Revista de } \\
\text { administração de } \\
\text { empresas. } \\
\end{array}$ & $\begin{array}{l}\text { Seek to obtain the keys to the } \\
\text { success of your legacy and the } \\
\text { repercussion at the tourist level. }\end{array}$ \\
\hline $\begin{array}{l}\text { Mega events, politics and Legacy: Brazil as } \\
\text { host of the FIFA World Cup } 2014 \text { and the Rio } \\
2016 \text { Olympic and Paralympic Games }\end{array}$ & $\begin{array}{l}\text { Almeida, } 2016 . \\
\text { Espacio abierto. }\end{array}$ & $\begin{array}{l}\text { Importance of case studies with a } \\
\text { dialogue with the past to identify } \\
\text { common ground. }\end{array}$ \\
\hline $\begin{array}{l}\text { Civil society and conflicts in the construction } \\
\text { of sport mega events in Brazil }\end{array}$ & $\begin{array}{l}\text { Amaral et al, } 2014 . \\
\text { Sociedade e Estado. }\end{array}$ & $\begin{array}{l}\text { Civil society has organized itself } \\
\text { using different forms of action in } \\
\text { the fight against the violation of } \\
\text { rights. }\end{array}$ \\
\hline $\begin{array}{l}\text { Mega-sport events and their Legacies: an } \\
\text { analysis of the institutional effects of the } \\
\text { election of Brazil as host country }\end{array}$ & $\begin{array}{l}\text { Toledo et al, } 2015 . \\
\text { Revista de sociologia } \\
\text { e Política. }\end{array}$ & $\begin{array}{l}\text { It contributes to the literature in that } \\
\text { it adds a new methodological } \\
\text { guideline and a new analytical } \\
\text { dimension. }\end{array}$ \\
\hline $\begin{array}{l}\text { Paradiplomacy and the international } \\
\text { competitiveness of cities: the case of Rio de } \\
\text { Janeiro }\end{array}$ & $\begin{array}{l}\text { Mendes, } 2017 . \\
\text { Revista Brasileira de } \\
\text { Política Internacional. }\end{array}$ & $\begin{array}{l}\text { The international involvement of } \\
\text { Rio de Janeiro grew after the } \\
\text { announcement as host of the } 2016 \\
\text { Olympics. } \\
\end{array}$ \\
\hline $\begin{array}{l}\text { The impact of sports mega-events on health } \\
\text { and environmental rights in the city of Rio de } \\
\text { Janeiro }\end{array}$ & $\begin{array}{l}\text { Vilani; Machado, } \\
\text { 2015. Cadernos de } \\
\text { Saúde Pública. }\end{array}$ & $\begin{array}{l}\text { Urban planning is guided by the } \\
\text { market, with failures in improving } \\
\text { public health and environmental } \\
\text { sanitation. }\end{array}$ \\
\hline
\end{tabular}

We note that most of the selected articles are from before the event occurs. Two articles are from the year the event occurred and only one was after the event. This corroborates with our initial hypothesis of greater discussion of legacies before the event occurs and a reduction of the debate after the event.

Demarzo et al. (2014) affirmed, before the games took place, the need to evaluate the impact of the Olympic Games on the health of Brazilians. Like London 2012, a partnership with SUS (Sistema Único de Saúde - 
Brazilian national health system offered by the state to the population) could have been established in the evaluation of this impact.

Maturana (2014) said that greater investments are needed in studies and interventions that will discuss the aspects of the Education of the Olympism in a broader way. Vila et al (2014) worried about another dimension, saying that it was necessary to seek the keys to the success of their legacy and the repercussion at the tourist level.

Amaral et al (2014) focus on a point that had much media repercussion, that were the social issues and how the civil society has organized using different forms of action in the fight against the violation of rights.

Toledo et al. (2015) have brought a contribution to the literature closer to the event as it adds a new methodological guideline and a new analytical dimension.

Vilani and Machado (2015) have returned their analysis to the question of how urban planning is oriented by the market, with failures in the improvement of public health and environmental sanitation.

Pereira (2016) in the year of the event affirms the need to implement a National Sports Policy, with regular practice, curricular and pedagogical Physical Education.

Almeida (2016) reminds us of the methodological importance of case studies as a dialogue with the past to identify common points. And finally Mendes (2017) after the event, says that the international involvement of Rio de Janeiro grew after the announcement as host of the 2016 Olympics.

\section{CONCLUSIONS}

We perceive the variety of approaches explored by the authors and the impossibility of trying to understand the phenomenon of the Olympics that occurred in Rio, in 2016, from just one perspective.

We believe that if we run the criteria of the systematic review again on the current date or later, we will have new entrances and a new way to understand the phenomenon. So, further analysis could be the key to an extended understanding of this historical fact.

Through the technique of systematic review, it was concluded, after reading and analysing the selected articles in the indicated period, that the following possibilities and dominant themes of the debate were found about legacies: multidisciplinarity, education, public health, inclusion, politics, social conflicts and environmental rights.

\section{REFERENCES}

Almeida B.S. (2016). Megaeventos esportivos, política e Legado: o Brasil como sede da Copa do Mundo Fifa 2014 e os Jogos Olímpicos e Paralímpicos Rio 2016. Espacio abierto. https://doi.org/10.1590/s0101-32892014000200012

Amaral et al (2014). A sociedade civil e os conflitos na construção dos megaeventos esportivos no Brasil. Sociedade e Estado. https://doi.org/10.1590/s0102-69922014000200015 
Cordeiro, A..M.; Oliveira, G.M.; Renteria, J.M.; Guimarães, C.A (2007). Revisão sistemática: Uma revisão narrativa. Rev Col Bras Cir., GERSRio, p. 34 - 36. https://doi.org/10.1590/s010069912007000600012

Demarzo et al (2014). Legado olímpico para o Brasil: questão de saúde pública? Cadernos de Saúde Pública. https://doi.org/10.1590/0102-311xpe010114

Gil, A.C. (2008). Métodos e técnicas de pesquisa social. 6 ed. - São Paulo: Atlas.

Internacional Olympic Committee (2014). Olympic Agenda 2020 20+20 Recommendations. Lausanne: IOC.

Maturana, Leonardo (2014). Olympic education for what? Olympic education for whom? Representations and practices for critical pedagogy in special topics of olympism-the doping between school. Podium.

Mendes M.V.I. (2017). Paradiplomacy and the international competitiveness of cities: the case of Rio de Janeiro. Revista Brasileira de Política Internacional. https://doi.org/10.1590/0034-7329201700103

Pereira A.M. (2016). Legado Olímpico: uma herança multidisciplinar. Motricidade.

Tavares, Otavio (2011). Megaeventos Esportivos. Movimento, Porto Alegre, v. 17, n. 3, p. 11-35, jul/set. 2011. https://doi.org/10.22456/1982-8918.23176

Toledo et al (2015). Megaeventos esportivos e seus Legados: uma análise dos efeitos institucionais da eleição do Brasil como país-sede. Revista de sociologia e política. https://doi.org/10.1590/1678$\underline{987315235602}$

Vila et al (2014). Olympic and paralympic games in Brazil: learning from Barcelona and Sydney. Revista de administração de empresas.

Vilani; Machado (2015). The impact of sports mega-events on health and environmental rights in the city of Rio de Janeiro. Cadernos de Saúde Pública. https://doi.org/10.1590/0102-311x00047414

Villano, Bernardo et al (2008). Seminário "Gestão de Legados de Megaevento Esportivos": Pontos de Convergência. In: Dacosta, Lamartine et al (Org.). Legados de megaeventos Esportivos. Brasília: Ministério do Esporte, p. 47-50. https://doi.org/10.5007/2175-8042.2013v25n41p42

\section{(9) $(\mathbb{\Theta \Theta}$}

This work is licensed under a Attribution-NonCommercial-NoDerivatives 4.0 International (CC BY-NC-ND 4.0). 